\title{
The effects of the War on the Syrian Agricultural Food Industry Potential
}

\author{
Mustafa Bayram ${ }^{1, a, *}$, Yasemin Gök ${ }^{1, b}$ \\ ${ }^{1}$ Department of Food Engineering, Faculty of Engineering, University of Gaziantep, 27310 Gaziantep, Turkey \\ ${ }^{*}$ Corresponding author

\begin{tabular}{l|l}
\hline A R T I C L E IN F O & A B S T R A C T \\
\hline Review Article & $\begin{array}{l}\text { Syria is a middle-income developing country with an economy that heavily depends on the food and } \\
\text { agricultural sectors. However, with the recent Syria crisis/war, which started in March 2011, Syria's } \\
\text { food and agricultural industries have badly been affected. While the most of the processing factories } \\
\text { and agricultural facilities such as industrial zones, food plants, greenhouses, irrigation canals and } \\
\text { pumps have been damaged in the conflict areas, this resulted in a huge recession in the food and } \\
\text { agricultural productivity of Syria. It is estimated that this will impact the country to meet the future } \\
\text { food requirements as well. In this study, the agricultural and food potential of Syria was analysed } \\
\text { based on agricultural area, available lands, irrigation, food sectors etc. for the future planning food } \\
\text { policies. }\end{array}$ \\
$\begin{array}{l}\text { Received : 25/12/2019 } \\
\text { Accepted : 07/07/2020 }\end{array}$
\end{tabular} \\ Keywords: \\ Syria \\ Food \\ Agriculture \\ Food industry \\ Economy

\section{Introduction}

The objective of this study is to plan the food sector in Syria for the end of the war by perceiving specific shortcomings of the previous failed attempts. As the main food industries of Syria are based on agriculture and food, mainly it is concentrated upon agricultural-food development. In this study, the potentials of food industry and agricultural sectors were evaluated.

In order to evaluate the future of Syria's economy and food plant investment, this study can help to investors, economists and strategists. It can also help to prepare new feasibility studies related to the Syrian food sectors.

The data about Syria for the period of crisis/war are very limited. Therefore, the foresight about the future of food in Syria is critical by using all available data in the literatures.

\section{Geography}

The Syrian Arab Republic is a Middle East country situated on the eastern end of the Mediterranean Sea with an $185,180 \mathrm{~km}^{2}$ total area and bordered in the north by Turkey, in the west by Lebanon, in the east by Iraq and in the south by Jordan and Israel (FAO, 2005). The country has maritime boundaries with Lebanon, Cyprus and Turkey (European Commission, 2011).
The Syrian Arab Republic geographically has been divided into four regions, which are the coastal, the mountainous, the interior and the desert regions (Almadani, 2014). Additionally, for administrative purposes, Syria is divided into fourteen provinces, one of which is the capital Damascus and the others are Aleppo, Al-Hasakah, Al-Suwayda, Daraa, Deir Ez-Zor, Quneitra, Homs, Idleb, Hama, Lattakia, Rif Dimashq, Ar-Rakkah and Tartous (Frenken, 2009).

In the country, pastures, steppe land and forests cover $48 \%$ of the total land, cultivable lands constitute $32 \%$, where the remainder is rocky mountains and desert. Cultivable land is split into cultivated (92\%) and uncultivated lands (8\%) (Shhaideh et al., 2000). The desert areas of the country are used for grazing when there is adequate precipitate (Hassan and Krepl, 2014). Concerning forests, even though they have an essential role in the realm of economic, social and environmental aspects due to the wide-scale land clearing for human settlements and agriculture, illicit lumbering, grazing by livestock animals, burning for the production of charcoal, fires and inappropriate agricultural practices, there has been a considerable loss in the forest landscapes. Consequently, they cover only $3 \%$ of the total country land (Shhaideh et al., 2000; Sarris, 2001). 


\section{Climate}

In the Syrian Arab Republic, the climate type is the Mediterranean with four seasons: cool rainy winters, warm dry summers, relatively short spring and autumn (FAO, 2008). The coastland regions are characterized by a mild Mediterranean climate, while the interior parts are considerably continental with hot summers above $40^{\circ} \mathrm{C}$ and cold winters below $0^{\circ} \mathrm{C}$ (Masri, 2006).

Temperature variation between day and night of the Syrian Arab Republic is extremely high with a maximum difference of $32^{\circ} \mathrm{C}$ in the interior and around $13^{\circ} \mathrm{C}$ in the coastal region. Total annual rainfall ranges from 100 to $150 \mathrm{~mm}$ in the northwest, 150 to $200 \mathrm{~mm}$ from the south towards the central and east-central areas, 300 to $600 \mathrm{~mm}$ in the plains and along the foothills in the west and 800 to $1,000 \mathrm{~mm}$ along the coast, increases up to $1,400 \mathrm{~mm}$ in the mountain regions. The annual precipitation in the country is approximately $252 \mathrm{~mm}$ (FAO, 2008). Over 80 percent of the annual rainfall is concentrated in winter from October to April. There is almost no rainfall between June and September (The World Bank, 2001).

Since Syria is a semi-arid country, the agricultural sector heavily depends on the timing and amount of precipitation (The World Bank, 1987). However, the economic activities of Syria such as agriculture and light industry have caused unplanned urbanization, overutilization of water resources and land, deficiency of waste treatment and deforestation. All these destructions have led to climate change, which has resulted in a significant reduction in the rainfall of the country (Melhem and Higano, 2001).

\section{Population}

Syria, in the history, was a homeland for many civilizations such as Sumerians, Egyptians, Hittites, Assyrians, Babylonians, Persians, Turks, Arabics and the Seleucid Empire and the country had a significant role for trade and industry in the ancient ages due to its location.

In the first years of the country, the population was around 3.5 million (Commins, 2004). According to the World Bank records, one year before the crisis/war, in 2010, the population of the country increased to 21,018,834 (The World Bank, 2018).

While Syria is entering its seventh year with the crisis/war, more than 500,000 Syrians died, half of the population left their homes and migrated to neighbouring countries, mostly Turkey, Egypt, Jordan, Iraq and Lebanon, with some fled for Europe (Amnesty International, 2013; Reuters, 2018). As of October 7, 2018, the population of the country estimated as $18,430,453$ based on the latest World Bank records (The World Bank, 2018).

\section{Economy}

Syria used to be a middle-income developing country with an economy mainly dominated by the oil and the agricultural sector, which together accounted for half of Gross Domestic Product (GDP), where the contribution of agriculture used to be nearly 30 percent, employing 25 percent of the total labor force with another 50 percent dependent on it in the manufacturing sector (IBP, 2015; The World Bank, 2001).

In 2000, the economy of Syria attempted to pass liberal economy and innovations were performed such as opening up the market to foreign investors, licensing foreign banks to operate within the country (Raphaeli, 2007). In the recovery process of the economy, the government implemented many innovations including allowing new private-sector banks to operate, policies for the reduction of borrowing interests and government subsidies in agricultural and industrial sectors (Çakmak and Ustaoğlu, 2015). Moreover, the first stock exchange of Syria, Damascus Securities Exchange was opened in 2009 for upgrading Syria's financial system and encouraging foreign investments (Rafei, 2009).

In addition to the global financial crisis and the sanctions, the macroeconomic performance of Syria was affected by long-term droughts, which dropped the agricultural output (Feldman, 2007). The poor climatic conditions caused the share of the agricultural sector to decline to about $17 \%$ of 2008 GDP, which was $20.4 \%$ in 2007 (IBP, 2015). Even though Syria was showing an improvement towards economic reforms and succeeding access to universal primary education, reducing the gender gap in education, decreasing the mortality and enhancing immunization coverage among children, poverty, which was falling between 1997 and 2004, had shown a rise in the second half of 2000s (Gobat and Kostial, 2016).

Even the impacts of the global crisis in 2009 had been relatively moderate and the slight impact was mostly because of the decrease in exports to trade partners in Europe and the Middle East and resulted in 1 percent reduction in GDP, about 4 percent decrease in the exports of commodities and services, and the increase of unemployment to $11 \%$ from $9 \%$ (Bloomsbury Publishing, 2010). However, the effects of the global crisis were temporary and the trade flows rose again in 2010 (Mohsen et al., 2016). Consequently, before the long-term effects of the economic recovery were observed, the war began in 2011 and the economic balance of the country was devastated inevitably (Çakmak and Ustaoğlu, 2015).

Before the conflict, the major trading partners of Syria were the European Union (EU) and Arab countries (AlHamwi, 2005). The EU represented a significant export market for oil, in addition to some other Syrian commodities. The Arab countries were the second largest export destination for mainly food products such as cereals, vegetables and fruits (Abbas and Procházka, 2010).

Syria also used to be a transit route for agricultural and food exports from Jordan, Lebanon and Iraq to the black sea markets and the EU, and from Lebanon and Turkey to Jordan and the Gulf. However, the trade dynamics in the Middle East have been affected by the crisis/war and as new export routes have been emerging, trade volumes and flows have changed significantly (RFSAN, 2016).

The especially conflict-related disruptions and international sanctions imposed on Syria had a very significant impact on the economic recession of the country, as exports decreased by 92 percent between 2011 and 2015. Also, the account deficit in 2016 widened 
sharply to 28 percent of GDP from 0.7 percent of GDP in 2010. Moreover, the number of foreign reserves fell to US $\$ 1$ million in 2015 from about US $\$ 21$ billion in 2010 (World Bank Group, 2017).

In 2015, the economy of Syria is struggling with many severe complications for growth, such as poor performance in the public sector, decline and depletion in the rates of oil, large-scale corruption, financial weaknesses of capital markets, high unemployment rates as a result of rapid population growth and increased labor force participation (IBP, 2015).

According to a report of Business Monitor International (BMI) Research, it was forecasted that the economy of Syria, annually would decline by 3.9 percent from 2016 to 2019, which would bring its economy back in the 1990s and would make the country dependent on investments from Iran and Russia (Holodny, 2016). The cumulative GDP loss was 226 billion USD from 2011 to 2016. When this forecast was analyzed, it was predicted that Syria economy continued to decline between 3 and $4 \%$ annually.

\section{Agricultural Zones of Syria}

For agricultural and food planning purposes, the land in the Syrian Arab Republic is classified into five agroecological settlement zones based on the rainfall temporal distribution and amount per year, which are mainly specified according to land use, crops grown and crop rotations as following (Figure 1) (Al-Ashram, 1990).

Zone 1: This zone, where annual rainfall exceeds 350 $\mathrm{mm}$, includes the coastal area, the Golan Heights, the northern part of Aleppo Governorate, the borderline with Turkey and the mountainous region in Suweida by covering nearly $15 \%$ of the total area of Syria (Saker et al., 2001). Summer crops such as melon and watermelon, fruitful trees and early vegetables, accompanied by barley, wheat, corn, sugar beet, cotton, etc. and almost all tobacco were planted in this zone, where high rainfall permits the agriculture of variable crops (The World Bank, 2008; FAO, 2003; Saker et al., 2001).

Zone 2: The annual rainfall amount of this area is between 250 and $350 \mathrm{~mm}$, which constitutes $13.4 \%$ of the total area of Syria, where the main crops are barley, wheat, legumes and summer crops (FAO, 2003).

Zone 3: The annual rainfall amount of this area is between 200 and $300 \mathrm{~mm}$, which constitutes $7.1 \%$ of the total area of Syria, where the main crop is barley. However, legumes can also be grown (FAO, 2003).

Zone 4: The annual rainfall amount of this area is between 200 and $250 \mathrm{~mm}$, which constitutes $9.8 \%$ of the total area of Syria, where the main crops are barley and permanent pastures (FAO, 2003).

Zone 5: The annual rainfall amount of this area is less than $200 \mathrm{~mm}$, which constitutes $55.1 \%$ of the total area of Syria, where the main vegetation is desert and rangelands (Omar, 2002). This area is not suitable for rainfed plantation, it is mostly used for natural grazing of sheep and camels (Cafiero et al., 2009).

\section{Agriculture in Syria before Crisis}

Agriculture has been the mainstay of the Syrian economy with 6,025 million ha agricultural land, which represents $22.34 \%$ of the total area (Erian et al., 2010;
SEF and Syrian Economic Task Force, 2017). The average share of agriculture in gross national products of Syria changes between 20 and $27 \%$ depends on the year. For example, it was around $20 \%$ in 2007 according to reported values.

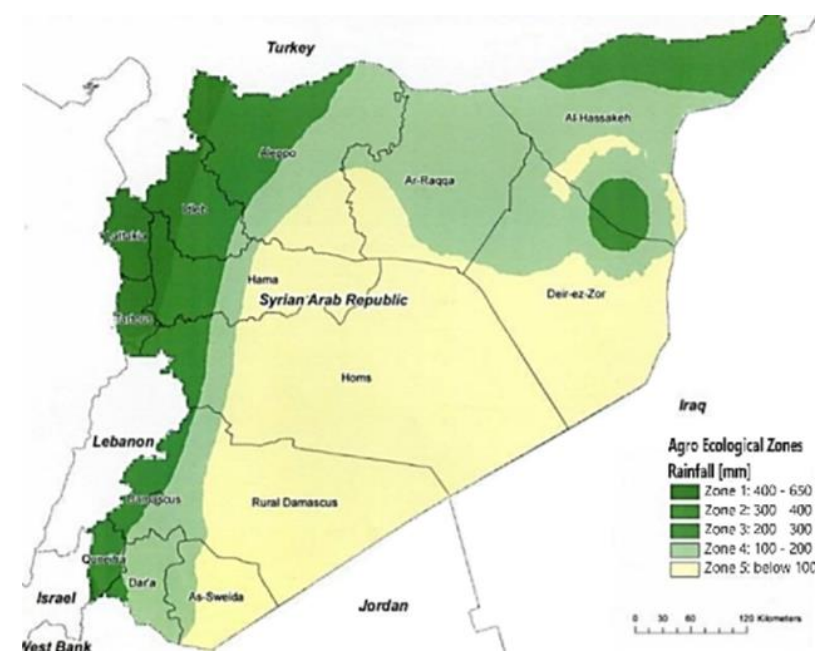

Figure 1. Agricultural stability zones in Syria (modified map from FAO, 2018)

Agriculture has also a vital role in providing raw materials for the food manufacturing sector of the food industry as well as generating employment opportunities (Hassan and Krepl, 2014). While almost half of the population lives in rural areas, in 2008 the labor force in agriculture was $20-25 \%$ of the country's total population, which is more than any country in the Middle East and North Africa region except Yemen (The World Bank, 2008).

The main crops of the country are wheat, barley, lentil, chickpea and cotton (Omar, 2002). Also, for the arid and semi-arid areas, where irrigation water and rainfall are insufficient, the rearing of livestock, especially sheep, goat and camel is the most important agricultural activity (Khoury, 2011).

In general, agriculture in Syria has suffered from the declines in precipitation, increasing urbanization of cultivable lands, the salinization of irrigated areas (Euphrates region) and desertification (SEF and Syrian Economic Task Force, 2017). In addition to these challenges, Syria experienced a catastrophic drought between 2006 and 2011, which was estimated as worst in the last 900 years (Stokes, 2016). Since the rain-fed agriculture areas represent around $71 \%$ of the total agriculture lands in Syria, this caused 1.5 million of Syrians to migrate to urban cities like Homs and Damascus in search of alternative work after infertile years because of the drought (Erian et al., 2010; Stokes, 2016). According to United Nations, the drought led $75 \%$ of Syria's farms to fail and $85 \%$ of livestock to die (Stokes, 2016). Especially the provinces such as AlHasakah, Ar-Raqqah, Aleppo or Halab, and Dier ez-Zor, which supply 75 percent of the total wheat production in Syria were badly affected (Erian et al., 2010).

The contribution of agriculture to the country's GDP was $25 \%$ before the drought and dropped to around $17 \%$ in 2008 (Kelley et al., 2015). However, according to Trading Economics data, despite the severe drought, the 
Syrian Arab Republic's economy showed regular progress between the years of 2000 and 2010, while the population of the country was showing a rapid increase as well (Trading Economics, 2017). This economic growth was maintained mainly by the transportation, communications, finance, manufacturing, real estate and construction sectors. Meanwhile, agriculture's contribution was considerably low (roughly less than $20 \%$ in GDP) (FAO, 2016a).

\section{Effects of the Crisis on Agriculture and Food Industry}

The agricultural sector of Syria has experienced many severe crises because of droughts (2008), increasing urbanization of arable lands (last quarter), the salinization of irrigated lands (Euphrates region), desertification in the desert and the marginal areas, misadministration of water resources, retarded implementation of important projects, such as the adoption of neo-liberalization policies in prices of energy and fertilizers and modern irrigation systems (Nasser et al., 2013; SEF and Syrian Economic Task Force, 2017). In addition to these problems, the ongoing crisis has caused losses and enormous damage to the agricultural production (FAO, 2017a). It also affected job creation, prices of goods and food safety, and eventually the economy of the country (Nasser et al., 2013).

The FAO Report published in 2013 states that while the conflict is continuing, the agricultural production of the country also keeps dropping, where wheat and barley production has shown a drop; fruit trees $55 \%$ and olive oil production $40 \%$ and vegetables $60 \%$ drop (Jaafar et al., 2015).

The effects of the conflict include not only the decrease of crop production, disruption in the supply of agriculture inputs and reduction in livestock numbers, but also the irrevocable destruction of properties, such as farm machinery and storage, irrigation systems and processing facilities (FAO, 2016a). Assessments also demonstrate that the increased transportation costs as a consequence of increased fuel prices and insecure roads have resulted in higher prices in agricultural inputs and marketing (ACAPS and MapAction, 2013).

The conducted research by FAO shows that the ongoing crisis has caused more than $\$ 16$ billion total bill damage to farming assets, crops and livestock sector. While the estimated loss in the crop production is about $\$ 6.3$ billion of the total, it is calculated at around $\$ 5.5$ billion for the livestock sector and $\$ 80$ million for the fisheries sector. The report states that dependently on how the conflict develops, rebuilding the agricultural sector would cost between $\$ 10.7$ and $\$ 17.1$ billion over the first three years (FAO, 2017b).

\section{Water Resources in Syria}

In Syria, water resources have a crucial role in the progress and expansion of economic activities such as agriculture, industry and tourism in addition to their domestic consumption (Kaisi et al., 2006), where the largest amount of water is consumed in agriculture, over 85 percent, just like the other Middle East and North Africa (MENA) countries (The World Bank, 2001). However, Syria is considered as semi-arid with two-thirds of the land being desert and the water resources are very limited compared to the needs of the country (Asmael et al., 2015; Chapman, 2014). Additionally, Syria has been heavily facing climate effects on water resources. Aquastat data shows that the total renewable water resources per capita were $908 \mathrm{~m}^{3} /$ capita/year between the years 2013 and 2017 (AQUASTAT, 2018), while 500$1000 \mathrm{~m}^{3} /$ capita/year is considered as high water stress (Kummu et al., 2010). Moreover, annual available water per capita in Syria will decrease from 2,684 $\mathrm{m}^{3}$ in 1970 to $620 \mathrm{~m}^{3}$ in 2025 (Mourad and Berndtsson, 2012a). AwHassan et al. (2014) are anticipating a climate change to decrease these resources far more than expected, considering that half of the annual renewable water resources of Syria take their source from the cross-border flow, with the large amount of them flowing in from Turkey through the Euphrates.

In Syria, the total estimated water use volume is about 15 $\mathrm{km}^{3} /$ year (The World Bank, 2001), where rainfalls provide the main source of the water, which corresponds to 68 percent of the total water resources (Shhaideh et al., 2000). However, while the falling rainfall amount is around 45 $\mathrm{km}^{3} /$ year because most of the water evaporates or seeps into the underlying aquifers, the contribution of precipitation to the country's surface water resources is estimated to be at around $9 \mathrm{~km}^{3} /$ year (Işıklı et al., 2007). Other water resources of the country are rivers (23\%), springs (6\%) and underground water (3\%) (Shhaideh et al., 2000).

The rivers in Syria constitute the second largest source, which provides $37.52 \mathrm{~km}^{3}$ flow per year. However, Syria is not able to tap all the water due to the limitations by international agreements with the neighbouring countries. Therefore, the total renewable water sources from rivers are limited to $8.34 \mathrm{~km}^{3} /$ year regarding influx and outflux. The influx and outflux of groundwater of the country are also limited by the legal decisions, where the total renewable amount is around $1.33 \mathrm{~km}^{3} /$ year (Chapman, 2014).

In 1986, a law was issued for water resources assessment and management throughout the country and Syria has been divided into seven water basins according to their geological, hydrological, demographical and meteorological characteristics: Barada and Awaj (Damascus), Al-Yarmouk, Orontes (Al Assi), Euphrates and Aleppo, Desert (Steppe), Dajleh (Tigris) and Khabour and the Coastal Basin (Mourad and Berndtsson, 2012a; Kaisi et al., 2006).

All these basins differ in size, rainfall levels, and water volume and among them, Euphrates and Tigris basins provide the largest amount of total renewable water and originates their sources from the surface water. For the other river basins, the primary source of water is groundwater (UNW-AIS, 2008). However, the most of the water basins are polluted by nitrates and other chemicals used in agriculture, wastes of factories, sewage water and petroleum refineries. As a result of misusage of water, there has been a considerable reduction in water inflow and more is expected for several other reasons such as drought and population growth which might result in a water crisis (Hinnebusch et al., 2011).

Besides the existence of basins, which are the primary source of surface water, 166 dams were also constructed to increase irrigated areas and control usage of water (FAO, 2008; The World Bank, 1987). Al Tabqa dam is 
the largest one among all which was built on Euphrates basin in 1973, located at al-Thawrah district of the ArRaqqah Governorate in northern Syria and it was anticipated to extend the irrigated area of Euphrates basin by 640,000 hectares. However, the plan did not work as expected because of gypsum terrains caused collapses on the network and in the end, only 200,000 hectares had been irrigated. Moreover, 3,000 hectares of this irrigated area are facing with soil salinity and drainage problems (Shapland, 1997).

\section{Irrigation}

In 1982, with the increasing demand for water for Syria's agriculture and overall economic development, irrigation became quite necessary, as the rainfalls of the country do not fall in the growing season and the Ministry of Irrigation has been established for the entire responsibility of water resources management such as (Kaisi et al., 2006); i) designing, operating and maintaining the sustainability of irrigation, wastewater systems and pumping stations, ii)assessment, protection and controlling pollution and use of water resources.

With the establishment of the Ministry of Irrigation, irrigated areas have increased substantially, which were around 450 thousand ha in the 1970 s corresponded to 14 percent of the total cultivated area. The cultivated land area in Syria was estimated at 4.5 million ha of which about 30 percent (1.3 million ha) was irrigated in 2011 (CBSS, 2017).

In the past, a substantial amount of the irrigation water was withdrawn from the surface water, where the Euphrates, Tigris and Khabour rivers have been the major sources, which are dependent on the seasonal rainfalls. However, since the availability of these waters was variable, that was affecting cultivation negatively. The dams and reservoirs also did not solve the availability of total water resources, which were convenient only to control and store water. After drillholes became common to supply water for domestic and agricultural uses, groundwater supplanted traditional surface water practices and became the major source of agricultural irrigation (Chapman, 2014).

For wheat and barley basin irrigation is the predominant method used. However, the efficiency of water is quite low (40-60\%) for the reason of excess irrigation with the traditional system. Even for the areas which are irrigated by furrows for the cultivation of vegetables and cotton, efficiency is still low because of the insufficiency of land leveling (Salman and Mualla, 2004).

In order to modernize and rehabilitate the use of groundwater and river water, a new policy strategy was announced by the Syrian Government Ministry of Irrigation in 2005, but implemented only from 2008 until 2011, at the beginning of the conflict in Syria. The major measures of the policy were limiting the extracted groundwater by applying penalty fees to farmers who are exceeding the allowed quantity per hectare established by law, authorization of drilling wells by issuing a license, installation of flow meters in wells and increasing the prices of groundwater pumping for adjusting to the diesel fuel prices (Aw-Hassan et al., 2014). However, the deficiency of legal controls over groundwater management caused overutilization and consequently salinity of groundwater, where almost $50 \%$ of privatelyoperated water wells were illegal in 2011, before the crisis/war. According to FAO Reports, a survey conducted by the Ministry of Water Resources in 2011 shows that 232,000 water wells exist in Syria while 115,000 of them were unauthorized (Dost et al., 2015). Moreover, the price of irrigation water was very low and not based on volumetric measures, which resulted in inefficient use of the resources (UNW-AIS, 2008).

The biggest challenge during the rehabilitation policies was the limited number of farmers investing in modern techniques. The main obstruct which restrained small farmers from investing in modernized irrigation techniques was the low financial capacity and doubts on financial returns of the advanced methods (Farahani et al., 2006).

Given the highly increasing water scarcity and food production needs of the population, it is required to adopt modern irrigation techniques, such as drip and sprinkler irrigation, the construction of lined canals or conveyance through pipeline connections from dams to farm gates and land leveling (Kaisi et al., 2006). It is estimated that the installation of the modern irrigation techniques, which was adopted only by $13 \%$ of the farmers in 2003 , could decrease average water consumption in irrigation from $12,434 \mathrm{~m}^{3} /$ ha to $8,000 \mathrm{~m}^{3} / \mathrm{ha}$ (Fiorillo and Vercueil, 2003; Peters et al., 2008).

Adopting modern irrigation techniques will not only decline the consumption of water but also increase the profit of farmers in the country. Based upon the conducted studies regarding the efficiency of sprinkler irrigation and drip irrigation, it is concluded that for surface water, profit of the farm can increase by $38 \%$ with sprinkler irrigation and $67 \%$ with drip irrigation adoption. In case that the water is extracted from wells $50 \mathrm{~m}$ deep, profit of the farm can increase by $67 \%$ with sprinkler irrigation and 111 percent with drip irrigation method (Varela-Ortega and Sagardoy, 2003).

After the start of the crisis/war, irrigation canals or pumps were damaged or stolen in the conflict areas. This destruction has led to a significant decrease in irrigated areas, which was estimated at around 606,000 hectares in 2004. Also, the crisis has caused a high level of overutilization of groundwater and an increase of the danger of soil salinization (FAO, 2016a). Moreover, it was reported that the price of irrigation water has been soaring because irrigation is dependent on electricity provided by generators and the diesel fuel used to operate them (RFSAN et al., 2016), which are both experiencing the highest rates of the country (Nasser et al., 2013).

\section{Main Food Products}

As a benefit of the diversity in the agricultural landscape and climate of the country, the Syrian Arab Republic has been able to grow a wide variety of agricultural products. The most common agricultural products are cereals, legumes, fruits and vegetables, which increase the competitiveness of the products and allow modifying the constituents of the crop rotation to meet the requirements for both foreign markets and local consumers (Işıklı et al., 2007). 


\section{Cereals}

Along with maize and barley, wheat is the most important cereal crop grown in Syria, as it is used to make bread, which is an important nutrient of the Syrian diet (Tull, 2017).

Around 1.5 million hectares of land was estimated to be planted with wheat in 2003, which is equal to $27 \%$ of the whole cultivated area in Syria (Pala et al., 2003). The main wheat producing districts in Syria are Al Hassakeh, Aleppo, Ar-Raqqah, Idleb, Deir Ez-Zor, Hama, Daraa, Homs, Al Ghab, Sweida, Rural Damascus, Tartous, Quneitra and Lattakia (Cafiero et al., 2009). The Aleppo and $\mathrm{Al}$ Hassakeh districts are quite important, as these together provide more than half of Syria's wheat production (Hassan and Krepl, 2014).

In 1990s, a special attention was paid through new strategies on Syria's agriculture policy for improving the wheat productivity of the existing lands by collaborating with international centers such as CIMMYT (Central International Center for Maize and Wheat Improvement, Centro International de Mejioramiento de Maiz y Trigo) and ICARDA (International Center for Agricultural Research in Dry Areas). In order to achieve desired developments, many studies were performed such as developing stress tolerant wheat varieties, enhancing water wells and other irrigation systems, using chemical fertilizers and pest and weed control measures, which are more suitable for the conditions of the country and for encouraging farmers, organizing extension and credit institutions in addition to subsidies and price controls. These studies helped to mechanize the production (Pala et al., 2003) and concluded with a great success story. As a former wheat importer, Syria in the 1970s became selfsufficient in wheat production in early 1990s and a wheat exporter in 2000 s while the wheat area was kept almost the same. Thirty-two percent of this achievement was attributed to improved varieties, $27 \%$ to developed irrigated conditions, $18 \%$ to fertilizers and $23 \%$ to crop management and other inputs including farm mechanization and herbicides. According to ICARDA data, wheat production rose from 2.1 million to around 4.5 million tons between 1991 and 2004. Even during the severe drought which started in 2007 , productivity and output were relatively high (Tadesse et al., 2016).

In Syria, wheat is cultivated with two farming systems: irrigated and rain-fed, $45 \%$ and $55 \%$ of the wheat area, respectively (Bader et al., 2008). Most of the rain-fed wheat is grown in the comparatively high rainfall areas $(300 \pm 500 \mathrm{~mm}$ annual rainfall $)$ as well as in irrigated dry regions (<200 mm) (Pala et al., 2003). The irrigation in Syria is applied in two methods as flood and sprinkler, in which the most common practice is flood irrigation (Sadiddin and Atiya, 2009).

In Syria, durum wheat and soft wheat are produced during winter season, which's production percentages were $50 \%$ of soft flour and $50 \%$ of durum wheat flour. In 2008, the integrated flour production underwent a change and it began to be produced with the ratio of $75 \%$ of soft wheat flour to $25 \%$ of durum wheat flour. As a result of the change in the production percentages, the domestic consumption of soft flour rose with the production of white flour with several kinds of white bread, biscuits, cakes and suchlike. This change also has resulted in the increase of the durum wheat's surplus amount and the export quantity of durum wheat has increased. The remainder durum wheat is commonly used in a form called "bulgur" and wheat in lower quality is used by some food processing establishments to produce brown or yellow flour and bran for fodder (Karkout and Lancon, 2011).

According to FAO estimates, in 2015 the wheat production amount of Syria was $40 \%$ lower than the precrisis averages 2.445 million tons. It is also estimated that there was 800,000 tons of wheat deficit in Syria's national wheat requirement (FAO, 2016a).

After wheat, barley is the second important cereal crop grown in Syria, which is used as a cash crop and for feeding sheep, where the sheep production is a vital enterprise.

Barley is produced in a wide range of environment where annual rainfall amount ranges from $200 \mathrm{~mm}$ to 350 mm. Aleppo, Idleb, Sweida, Al Hassakeh, Deraa, ArRaqqah, and Hama are the main cities for production of cereals. The narrowest barley planted area is in Idleb, while the largest is found in Ar-Raqqah (Mustafa et al., 2006). Indeed, barley is planted on over 1.4 million hectares area in Syria which is equivalent about $27 \%$ of total Syrian cropped land (Cafiero et al., 2009). However, the product input is very low compared to the other crops because little use is made of improved varieties (Mustafa et al., 2006).

In the country, both black and while barley is cultivated, while the black barley is used by livestock farmers and the production amount exceeds white barley (Sadiddin and Atiya, 2009).

The average barley need of Syria is 2.3 tons/year. However, since it is mainly used as animal feed, the demand for barley fluctuates in Syria every year, depending on the livestock number, production amount and the available grazing crops. Consumption increases comparatively with the lack of grass in the Syrian steppe. Therefore, in the drought years and in order to meet the fodder needs of livestock, barley is imported (Al-Shareef, 2008). While the annual barley production is ranging every year due to the high climate dependence of yield, the average output of Syria is about 1 million tons (Cafiero et al., 2009). FAO reports state that in 2016, the production of barley decreased about $13 \%$ compared to 2011/12 season due to the war and migration of the farmers (FAO, 2017c).

Like barley, maize is also produced as a fodder crop in Syria. Before the crisis, the annual production of maize ranged between 150,000 and 200,000 tons (Dost et al., 2015).

\section{Legumes}

Legumes, in addition to their significant place in the country's economy, also provide nutritionally rich crop residues for animal feed during the summer and early autumn months and play an essential role in maintaining the productivity of soil as a break crop in cerealdominated farming systems (Mawlawi and Tawil, 1990; Mazid et al., 2009). In Syria, food legumes are mainly grown in Zone 1 and Zone 2, and chickpea, lentil and fava beans are the most commonly grown types (Mawlawi and Tawil, 1990).

According to the statistics published by the Syrian Ministry of Agriculture and Agrarian Reform (MAAR), 
lentil is the most important rain-fed food legume crop regarding the area planted, while chickpea is the second (Mazid et al., 2009). They are grown in different soil conditions, that chickpeas are predominated in wetter areas, lentils in drier (Belaid and Morris, 1991).

Chickpea is grown in all provinces of Syria, but it is slightly more important in some regions such as Aleppo, Idleb, Hama, Suweida, Daraa, Homs and Al Hassakeh. However, in spite of the importance of chickpea, their yield potential has been very low in Syria as a result of multiple constraints such as biotic and abiotic stresses and poor cultural practices (Mazid et al., 2009). Climatic conditions have been the most challenging problem for the production of chickpea, which is associated with irregular and low rainfalls and killing frosts in late March (Tutwiler, 1995). There was a decrease about $40 \%$ in the yield amount of chickpea because of severe drought the country faced between the years of 2007 and 2009 (FAOSTAT, 2018).

Lentil, which is considered as an essential dietary protein source for low-income households is well adapted to production in the winter season in Mediterranean climates especially predominated in the Northern farmlands of Syria. The provinces of Aleppo, Idleb, Hama and $\mathrm{Al}$ Hassakeh account for $80 \%$ of the yearly crop of the country, where Damascus and Al Suwayda (Horan) provinces account for $20 \%$ (Yadav et al., 2007). According to the FAOSTAT Statistics, the total harvested area for lentil was 100,721 ha, yielding a total lentil production of 102,461 tons for the year 2009. However, the ongoing crisis led the harvested amount to decrease by about $30 \%$ and the estimated production was 70,907 tons in 2014 (FAOSTAT, 2018).

Fava bean, which is also known as faba bean, is a good source of cheap-quality protein and it is cultivated in areas under irrigation or with high precipitation. In Syria, its production is concentrated in mainly coastal regions and provinces such as Aleppo, Damascus, Hama, Homs, Idleb and Quinetra. The approximate production amount in the coastal area and these provinces are respectively as following: 34, 23, 19, 11, 7, 3.5 and 2.5\% (Akem and Bellar, 1999).

\section{Fruits and vegetables}

The importance of fruit production in Syria increased during the last two decades before the crisis/war as the fruit cultivated areas doubled (Mourad and Berndtsson, $2012 b$ ). The major fruits and vegetables produced in the country are olives, tomatoes, almonds, grapes, pistachios, oranges, apples, potatoes and citrus fruits (Hassan and Krepl, 2014).

\section{Pistachio and almond}

For all Mediterranean countries, pistachio and almond are considered as very special and important fruits. They also require a Mediterranean climate for a good quality of fruit (Baysan, 2001). They both require dry and hot summers, frost-free springs and adequate precipitation during winters and springs except for pistachio nuts which require comparatively cold winter temperatures for bud break (Almadani, 2014; Baysan, 2001). Moreover, both can be produced in poor, rocky, stony and calcareous soil (Baysan, 2001).

Among the Mediterranean countries in pistachio production, Syria leads after Turkey and produces $13 \%$ of the total global market (Almadani, 2014). Pistachio production is centered in Hamah and Idleb, both constitute half of the harvested area in Syria and produced $60 \%$ of the total pistachio between 2005 and 2011. Between the years of 2009 and 2011, the harvested area was accounted for 57,747 ha with $6,596,000$ trees and the overall production was 55,000 tons (Almadani, 2014; FAOSTAT, 2018).

Almond, which is the other important fruit for Syria, has gained its importance after the 1990s. Comparison of 1990-92 and 2004-06 data show that almond production in Syria increased about $510 \%$ and $79 \%$ of almond production is covered by Homs in 2009-2012 (Cafiero et al., 2009; OCHA, 2014).

Grape

The grape cultivation is spread through Syria, while it is mostly concentrated in Rural Damascus, Homs, Hama and Aleppo. However, the production has been showing a decline since 1998 because of the replacement of grape harvesting with more profitable fruit species such as olive and apple (Baghasa, 2006b). The grape production was about 540,000 tons in 1998. The total production decreased to around 337,000 tons in 2011 and 260,000 tons in 2016 (FAOSTAT, 2018).

Before the crisis/war, the product exceeded the demand is exported mostly to Arab countries, such as Saudi Arabia, United Arab Emirate, Kuwait, Jordan, Oman, Qatar and Bahrain. Exporters mainly purchase fruit either directly from farmers or wholesale markets, but the shortcomings in the inadequate cooling systems in warehouses or delivery vehicles and ineffective packing materials are the main problems of the sector, which cause losses of the production and rejection of the delivered products (Baghasa, 2006b).

\section{Olive}

In Syria, the olive trees take the first place among other fruit trees, occupying 65 percent of the total cultivated area of fruit trees with 544,000 hectares and around 80 million trees (El Ibrahem et al., 2007). Owing to their adaptability feature in terms of the type of cultivated soil, different bioclimatic conditions, olive trees are found in many different environments and microclimates in the country (International Olive Council, 2012).

Olive farming in Syria (72.20\%) is centered around in the northwest (Aleppo-Idleb) and the coastal area (TartousLattakia) and the remaining (26.80\%) is spread out around the cities such as Al Hasakeh, Deir Ez-Zor, Homs, Hama, Damascus, Sweida, Daraa and Tedmor. More than 95\% of the cultivation depends on rainfed, remaining is irrigated (Damascus, Tedmor, and Daraa) (El Ibrahem et al., 2007). According to the statistics, in 2009, the olive sector accounted for $11 \%$ of the agricultural production of Syria and olive composed $9 \%$ of the total amount of exports (International Olive Council, 2012). Between 2007 and 2011 the olive production increased in stable. Then, it dramatically decreased between 2011 and 2014 from around 1,150,000 to 400,000 ton in contrast to slightly increase in the harvesting area (Figure 2). This fluctuations in the olive economics due to seasonal factors especially drought and decrease in the yield and available stocks.

Olive farming has a critical role in agriculture of Syria, which is considered as a traditional food because of its healthy and organoleptic characteristics and it provides income for more than 200,000 families directly or 
indirectly in Syria (El Ibrahem et al., 2007). For these reasons and its high percentage of production, in 2001 the Syrian government had paid particular attention to enhance and expand the agricultural role of olive in Syria's economy. Regarding the olive cultivation, investment and trade policies, the Syrian government took many important actions such as: reclaiming land, dispensing olive seedlings at subsidized prices, providing free Integrated Pest Management services for the production of pesticide-free olives, supporting import of new olive mills with the exemption of taxes, fiscal fees and municipal rates. Addition to these steps, Syria joined the International Olive Oil Council for adjusting Syria's olive oil standards to comply with the standards of the Council (Al Ashkar, 2006).

As a result of the efforts made for alternate bearing phenomena and increased number of olive trees, there had been an enormous growth in the olive production ( $\mathrm{Al}$ Ashkar, 2006; International Olive Council, 2012). The production amount reached up to $1,200,000$ tons in 2006s, which had been around 400,000 tons between 1990 and 1997 (Figure 2) (FAOSTAT, 2018). Today, the produced olive and/or olive oil is over the consumption of Syria, so there is a big loss in trading due to the crisis/war.

The olive growing industry in Syria is separated into two sub-sectors: table olive (green and black) and olive oil. After harvesting, raw olives are sorted and graded before processing. While large sorted olives are primarily used for olive oil production, which is sold to traders and wholesalers by producers after processing, table olives are directly sent to traders (SIM Team, 2018).

In 2013, the Syrian Ministry of Agriculture conducted a study and the study pointed out the existence of many difficulties in the olive oil sector as a result of the current situation in Syria, such as the increased fuel prices, lack of labor force, high transportation, fertilization, pruning and cultivation costs and rising wages (Al-Khatib, 2013). Moreover, exports of the country have been affected due to the lack of good quality control systems where the quality controls are being carried out manually and informally currently (SIM Team, 2018).

\section{Potato}

In Syria, potato cultivation is spread through a broad area from north-south mountain ranges to the intervening valleys parallel to the Mediterranean coast in the western part of the country. In this vast area, there are three main environments convenient for growing potatoes: with $30 \%$ of annual potato production in the highlands around Damascus at 700-1400 m of altitude, the internal regions at 200-250 m of altitude, including Homs, Hama, Al Ghab and Aleppo, which are representing $60 \%$ of annual potato production and coastal area near Lattakia and Tartous contributes remaining $10 \%$ of the annual production (Shalaby et al., 2007). Potato growing is involved in three seasons (spring, summer and fall) in Syria (Alammouri, 2008).

Most of the cultivation areas (98\%) are irrigated, whereas, in Lattakia and Tartous, production is dependent on rain-fed (2\%). Before the war, Syria consumed most of the produced potatoes locally and also made exports to some Arab countries such as Iraq, Jordan, Kuwait and the United Arab Emirates (Alammouri, 2008).

In 2010 , the cultivated area of potato in three seasons was 34,500 hectares and the total production was 673,200 tons in Syria (FAOSTAT, 2018). Even though it decreased drastically in 2013 compared to the previous years, which was mainly because of the declined harvested area and reduced supply of seed potato. The production again rose to 632,218 tons in 2016 (Figure 3) (FAOSTAT, 2018; Dost et al., 2015).

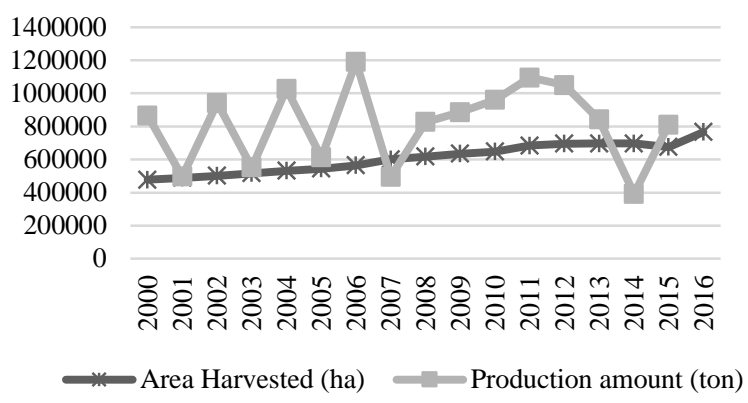

Figure 2. Olive production in Syria, 2000-2016 (FAOSTAT, 2018)

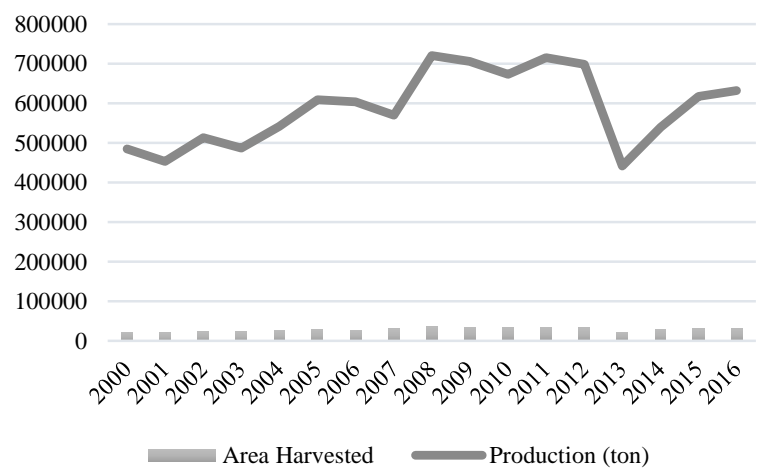

Figure 3. Potato production in Syria, 2000-2016 (FAOSTAT, 2018)

\section{Tomato}

Tomato as an indispensable nutrient for the cuisine of Syria and one of the most consumed products (Babili et al., 2016), it is also very important to farmers because of its high productivity and relatively low cost (Al-Hamwi, 2006). Food and Agriculture Organization (FAO) statistics show that in 2011, before the ongoing crisis Syria ranked as the nineteenth tomato producer with a 0.73 percent of total world production (Babili et al., 2016).

Tomato production in Syria mostly is carried on in open fields as moderate climate conditions allow, as well as in greenhouses in the coastal areas with heating and ventilation machinery, which provide climate control. Uncovered tomato production is grown in all governorates, but the total tomato production of Syria is predominated in Daraa, Aleppo, Al Hassakeh and $\mathrm{Al}$ Quneitra. The protected production is concentrated in provinces such as Lattakia, Tartous, Homs and Hama, which account for $11 \%$ of the total tomato production in the country (Figure 4) (Babili et al., 2016).

The produced tomato is divided into three groups: for local consumption, processing and export. While most field 
tomatoes are domestically consumed, the most protected tomatoes are exported to the Arab countries such as Saudi Arabia, United Arab Emirate, Kuwait and Qatar and the remaining is processed or exported to neighbouring countries. Domestically consumed tomato is either consumed fresh or processed, canned and packaged in local factories which are located in Daraa, Jableh, Rural Damascus and Al Hassakeh (Al-Hamwi, 2006; Babili et al., 2016).

With the current crisis, processing factories have been damaged and this has widened up the demand, which was already not meeting the need of the country regarding quantity and quality even before the war. The crisis affected not only the processing factories but also the production of the crop, while in 2012 unprotected tomato decreased by 56 percent compared to 2010 and protected tomato decreased by 40 percent (Babili et al., 2016). Moreover, 3,500 out of 5,700 greenhouses located in $\mathrm{Al}$ Baidaa and Al Bassateen villages in Banyas-Rural Tartous have been heavily damaged and it is not possible to operate the undamaged greenhouses due to the increased seed and fertilizer prices and water scarcity (UNDP, 2014).

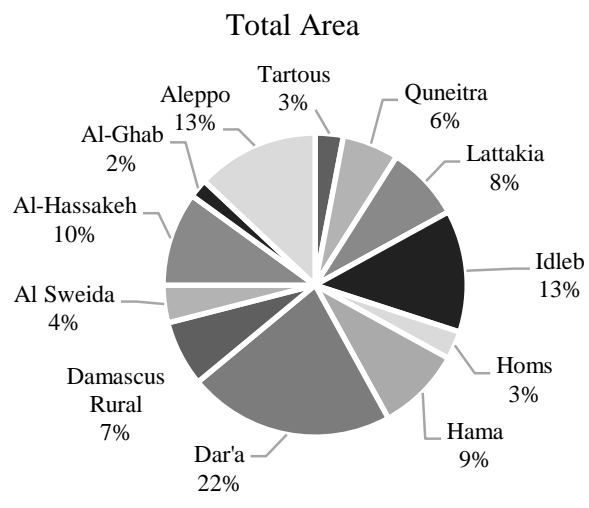

Production

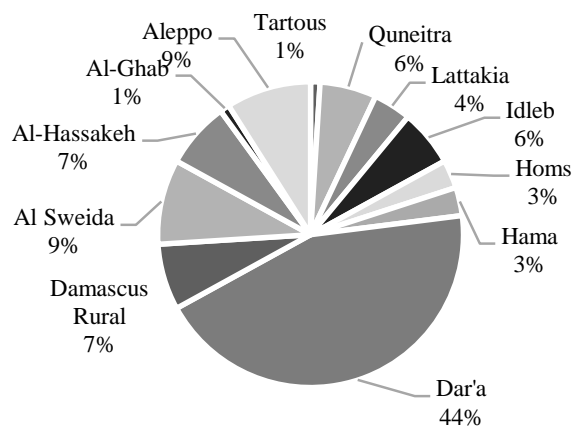

Figure 4. Uncovered tomato production and cultivated areas per governorate, 2013 (Babili et al., 2016)

Apple

Apple cultivation in Syria is centered at Rural Damascus, Sweida, Homs, Lattakia and Tartous, where irrigated areas constitute $35 \%$ of the total cultivated area. The main consumption form of apple is fresh apple, where consumption in the process of vinegar, juice and sugared apple constitutes only $5 \%$ of the total production (Hosni and Lancon, 2011).
While the exports and production of most of the other fruits have been declining, apple production has remained relatively unaffected, which was still higher in 2013 than its level in 2002 (FAOSTAT, 2018).

\section{Citrus}

The citrus sector in Syria, which was relatively unimportant until the establishment of citrus as an essential crop by the government in the 1970s. The government introduced and certified new and higher yielding citrus fruit varieties, provided public programmes and training in integrated pest management, subsidized farmers for land preparation, seedlings and inputs by providing a long-term interest-free credit between 1977 and 1993 (Westlake, 2000). After all these successfully implemented regulations, the citrus sector increased enormously and Syria became an exporting country in 2005, instead of an importing one (Mansour, 2007).

Also, the Citrus Board Directorate (CBD) stated that citrus fruits are the most promising products in Syria in the fruit production sector (Sheheilah, 2012):

Citrus production in Syria is concentrated in Lattakia (\%77) and Tartous (\%23) and it is also produced in small quantities in Homs, Idleb, Daraa, Deir Ez-Zor, Hama and Al Ghab. The most of the citrus production is irrigated through either public irrigation nets or by private wells by using both flood irrigation and drip techniques (Mansour, 2007).

The impacts of the war on the citrus sector have been slightly less than the other agricultural products even though most of the farmers had difficulties accessing fertilizer and pest control supplies due to the general deficiency and high costs. This is probably because most of the citrus-producing lands are located in governmentheld areas (Figure 5) (Dost et al., 2015; Westlake, 2000).

\section{Livestock Sector}

The Syrian Arab Republic is located on a 18.6 million hectares total area and around half of the country's land is categorized as pasture (Al-Badia, which covers 8.3 million hectares), which supplies about $15 \%$ or more nutritional requirements of the national sheep flock (Baghasa, 2006a). Moreover, the sector constitutes about one-third of the agricultural exports and 35\% of the total value of agricultural production (IFAD, 2012).

The composition of livestock is affected by many factors such as the amount of rainfall, availability of irrigation and forests, the development of markets for livestock products and evolvement of mechanization. For example, while Zone 2, Zone 3 and Zone 4 are predominated by cattle, Zone 5 is predominated by sheep. It is estimated that $88.79 \%$ of the total livestock population of Syria is composed of sheep, followed by goat with $5.9 \%$ and cattle with $4.66 \%$. The population of poultry is not included in this data (Peters et al., 2008). As the main livestock species in the country, poultry, few buffalo and camel have been grown as well (Dost et al., 2015). 


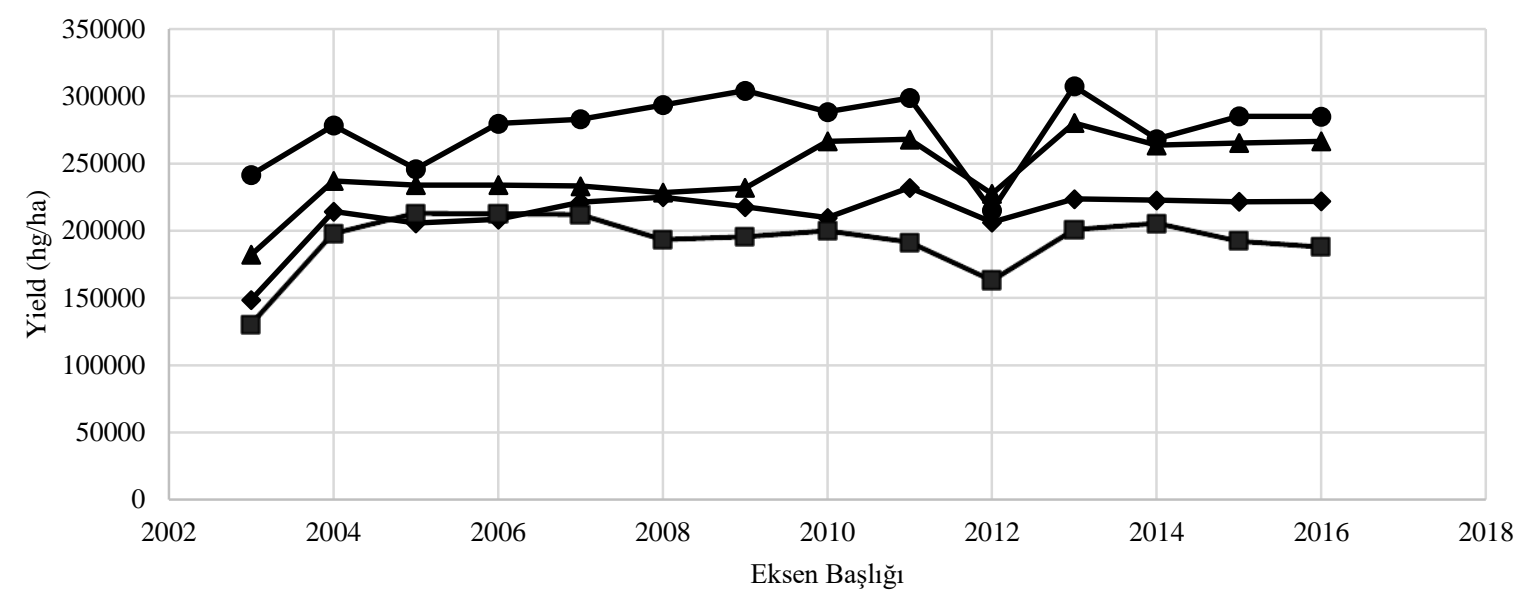

$\longrightarrow$ Grapefruit $\longrightarrow$ Orange $\longrightarrow$ Lemon and Lime $\rightarrow$ Tangerine, mandarin, clementine, satsuma

Figure 5. Citrus yield (hg/ha) in Syria, 2003-2016 (FAOSTAT, 2018)

Sheep is the most important livestock in Syria not only because it is a dominant livestock commodity, but also it provides an essential revenue since it is exported to the Gulf countries and the Kingdom of Saudi Arabia (FAO, 2016a).

The sheep population is concentrated in Al-Badia area with $70 \%$ and is distributed in other areas such as Deir Ez-Zor (16\%), Aleppo (16\%), Homs (14\%), Ar-Raqqah $(14 \%)$ and Hama (13\%) (Peters et al., 2008). The number of sheep in Syria peaked at 22.9 million in 2007, which had declined to the levels of about 18 million by 2011 and since then it is estimated it has become 10.8 million at present by a farther $40 \%$ decrease (FAO, 2016a).

Goats are found in many parts of the country but with a very low number. The goat population of the country was 2.3 million in 2011 and this number declined to less than 1.4 million with a $40 \%$ reduction (Dost et al., 2015). Apart from the effects of the ongoing crisis, the degradation of rangelands has been the primary constraint of grazing goat production (Masri, 2006). Additionally, the cattle population of the country was 1.1 million prior to 2011 and declined to around 778.000 by $30 \%$ reduction (Dost et al., 2015).

Syria's poultry industry started to develop in 1970 and it is dominated by commercial poultry (layers and broilers) in the urban and peri-urban areas (Subuh, 2008). However, intensification resulted in water pollution and land degradation in the country (Peters et al., 2008).

It is estimated that in 2008, there were 13,000 chicken farms in Syria producing 172,000 tons of meat and the sector was employing almost 150,000 people directly (Kharseh and Nordell, 2008). The largest poultry farms are centered around Rural Damascus, Homs, Al Hassakeh, Aleppo, Idleb and Hama (Subuh, 2008). Poultry industry started to increase just before the crisis/war. However, a lot of poultry farms were disrupted during the war.

In the Syrian Arab Republic, the development of the livestock sector has a significant impact on decreasing rural poverty and increasing employability. Prior to the ongoing crisis, $11 \%$ of Syria's total labor force was employed in the livestock sector, which included many low-income earners in rural areas. While the number of rural inhabitants was more than 8 million, 2.5 million of these were of low incomes. It was estimated that improving productivity could increase incomes and Syria's rural poor would benefit. However, increased livestock populations have resulted in land degradation and excessive grazing (Cummins, 2000).

The livestock sector in Syria has been poorly affected by the ongoing crisis and the prices of egg, milk and cheese increased remarkably by around 500 percent (Leigh, 2014). Another FAO situation report, published in September 2016 states that due to the limited access to the grazing pastures and 168 percent increase in the cost of animal feed, the numbers of cattle and sheep dropped by 30 and 40 percent, respectively. Therefore, livestock rearers had to slaughter more animals than usual to reduce economic losses (FAO, 2016b). Furthermore, poultry, which is considered as the primary animal protein source of Syria, has been the most affected sector with $50 \%$ reduction in the number of animals with the abandonment and destruction of farming units. The number of chickens dropped to around 13.1 million, which was approximately 26.2 million in 2011 (Dost et al., 2015).

It is forecasted for these percentages to increase as a result of the lack of routine veterinarian drugs and vaccines and further livestock owners will have to slaughter their animals (FAO, 2016b). Al Hassakeh, Deir Ez-Zor, Lattakia, Rural Damascus and Quneitra are the areas with the most loss of animals either by death as a result of lack of water, poor living conditions and killing or theft (Tull, 2017).

\section{Fishery Sector}

In Syria, the fishery sector plays a minor role in the economy due to the scarcity of resources and the low natural productivity of fishing grounds because of the high salinity of the coastal water, relatively low freshwater input and low tidal range. In addition to these, administrative and legislative constraints, such as discharges of untreated wastewater into seas and high level of pollution of the sea impacts the sector negatively (FAO, 2007; European Commission, 2011). Moreover, the yearly seafood consumption of the country is estimated at $1 \mathrm{~kg}$ per person, which is a quite low rate compared to the neighbouring countries (Ulman et al., 2015). 
Currently, the fishery sector in the country is divided into four: industrial (large-scale commercial), artisanal (small-scale commercial), subsistence (non-commercial, small-scale) and recreational (Ulman et al., 2015).

The main fish markets of the country are located in the north of Aleppo, Ar-Raqqah, northeast of Deir Ez-Zor, Homs, Hama, Lattakia, Tartous and Damascus. (FAO, 2007) Thus far, the most important types of fish groups are carps and tilapias for commercial aquaculture and tuna and tuna-like species, sea-breams, porgies, sardines, allies, jacks, scads, scorpionfishes and runners for the marine capture fisheries (FAO, 2007).

The impact of the fishery sector on the economy in Syria is neglect able. For example, the sector was contributing in 0.38 percent of the GDP in 2005 (FAO, 2007). However, according to an FAO report published in 2006, aquaculture is the most promising sub-sector, if the modern farming techniques are implemented correctly by using resources such as land, water and labor sustainably (FAO, 2006).

According to the FAO report published on May 2017, it is estimated that the total value of damage of the conflict to aquaculture and fisheries is nearly USD 80 million, of which USD 103,000 comprise of losses. Idleb (about USD 58 million), Hama (USD 15.4 million) and Ar-Raqqah (USD 4.8 million) have been the cities with the largest losses respectively (FAO, 2017a).

\section{Seed Industry In Syria}

The Syrian government shows a particular interest in agriculture because of its strategic importance to the country. The government takes charge of the supply and production of inputs including improved seeds. For this reason, the General Organization for Seed Multiplication (GOSM) was established by The Ministry of Agriculture and Agrarian Reform (MAAR) and it became operational in 1975 .

In order to encourage farmers to use certified seeds, sales prices were fixed at a lower level than the actual costs. For instance, in 1983, the sales price of GOSM was $70 \%$ lower than the actual costs (Mohammed, 1986).

Before the war, the processing of GOSM took place in 11 different branches located in various multiplication areas (Aleppo, Al-Hasakeh, Deir Ez-Zor, Ar-Raqqah, Idleb, Hama, Homs, Lattakia, Tartous, Damascus, Izraa), with a total of 100,000 tons/season storing capacity (GOSM, 2007). The FAO report published in 2015 shows that the storage capacity of GOSM has been declining significantly since 2011, as eight of its seed processing units have been damaged beyond repair or are in opposition-held areas or both. However, even this causes extreme difficulties to the organization in producing clean seeds; GOSM carries out providing seeds at subsidized prices within both Government-held areas and oppositionheld areas (Dost et al., 2015).

\section{International Food and Agricultural Trade in Syria}

\section{Food Exports in Syria}

Agricultural exports lead foreign currency earner in Syria and the sector has a significant contribution to industrial growth since agricultural raw materials are the source of many manufacturing activities (FAO, 2003).
For the years from 1980 to 2010 , the raw material export share was about $68 \%$, while the share of the total Syrian export for finished products and semi-finished products was $24 \%$ and $8 \%$, respectively (Mohsen, 2015).

In 2002 , the total exports of the country accounted for US\$7, 6 billion, as the contribution of agriculture was US $\$ 1$ billion and main exported agricultural commodities before the crisis were tomatoes, sheep, cotton, anise/fennel, sugar, potatoes, oranges, apples, olive oil, cattle, poultry meat and eggs (Abbas and Procházka, 2010; Dost et al., 2015). Tomato was one of the most critical exported vegetable in Syria, which took place on the top among the Syrian agricultural exports in 2011 and 2012 (Babili et al. 2016).

The livestock sector of Syria used to have a significant contribution to agricultural exports with 15 percent revenue and live sheep was the major contributor (Cummins, 2000). The primary market of livestock exports was oil-rich Arab countries, which provided a high income for livestock farmers and directly had an impact on the domestic prices of sheep products. In 2004, Saudi Arabia was the leading importer with 74 percent of total live sheep exports, which was followed by Lebanon, Kuwait and Qatar with 8-9 percentages for each (Shomo et al., 2010).

Jordan used to be Syria's largest cross-border agricultural partner, as the exports peaked in 2010. However, the exports to Jordan went into a decline during the period of conflict and decreased by $45 \%$ between 2011-2014 (RFSAN, 2016).

At the first stage of 2011, there was a remarkable displacement of industrialists and merchants to the relatively safe coastal areas under the government control and exports to Iraq, Jordan and Iran showed an increase due to the devaluation of the Syrian Pound (SYP) (Dost et al., 2015; Nasser et al., 2013). However, it halted after the devastation of production infrastructure and equipment (Nasser et al., 2013).

It is estimated that exports decreased about 38.4 percent at the beginning of 2012 and this decline reached up to 70 percent by 2015 as a result of the international embargo, the breakdown of border-cross trading and impact of the civil war on economic activities of the country (Gobat and Kostial, 2016; Nasser et al., 2013). The decreases in export volume have resulted in an ascend in the trade balance deficit, which has been one of the reasons of depreciation in the SYP (Nasser et al., 2013).

\section{Food Imports In Syria}

Before the war, the main imported goods in Syria used to be industrial and agricultural equipment, vehicles and heavy machines, where manufactured products were accounting for 87 percent of total imports in 2009 (IBP, 2015; Sleman and Farfour, 2012). The share of the agricultural products was around $11 \%$ and with sugar, maize and tea were comprising the bulk (Abbas and Procházka, 2010; Sleman and Farfour, 2012).

In 2009, most of the imports of Syria came from Asian countries (31.2\%), which was followed by the EU (23.6\%), non-EU European countries (18\%) and Arab countries (16.4\%) (Sleman and Farfour, 2012). 
Currently, for the opposition-controlled areas of northern Syria, Turkey has the largest import share, where Iraq comes second for manufactured foodstuffs such as rice, sugar, tea, lentils, bulgur, margarine and frozen chicken. Moreover, agricultural inputs (fungicides, pesticides and fertilizers) are also provided via the port of Mersin, Turkey. The most of the cross-border trade between Turkey and Syria is carried out through Bab alHawa and Bab es-Salam borders, which are only one-way trades as they are under a ban for exports from Syria to Turkey for the last two years (SIM Team, 2018).

\section{Conclusion}

Syria has still big potential about the food and agricultural sectors. After the crisis/war, these sectors will also be locomotive for the economy of Syria. Especially, cereals, vegetables, fruits, meat, dairy and fishery sectors are critical for the country. During this crisis/war, a lot of establishment, company, plant, industry and economical chain have collapsed. Important industrial zones in the conflict areas nearly collapsed. Additionally, professional human power related to food industry left from Syria. Therefore, there are a lot of gaps for the future. But, food is critical for Syria similar to other countries due to its importance to feed peoples.

During the crisis/war, local productions at different sectors continued to feed the local peoples. A restricted trading was also made with other countries. As soon as possible, a new food policy for the future of Syria should be made.

\section{References}

Abbas B, Procházka P. 2010. The effect of trade liberalisation on Syrian agriculture. Acta Universitatis Agriculture et Silviculturae Mendelianae Brunensis, 58: 665-672.

Akem C, Bellar M. 1999. Survey of Faba Bean (Vicia faba L.) Diseases in the Main Faba Bean-Growing Regions of Syria. Arab Journal of Plant Protection, 17 (2): 113-116.

Al Ashkar H. 2006. Olive Oil Comparative Advantages. Working Paper No: 19. Ministry of Agriculture and Agrarian Reform. National Agricultural Policy Center (NAPC).

Alammouri N. 2008. Agricultural Commodity Outlook of Syrian Potato. Ministry of Agriculture and Agrarian Reform. National Agricultural Policy Center (NAPC). Damascus, Syria.

Al-Ashram M. 1990. Agricultural Labor and Technological Change in the Syrian Arab Republic. In: Tully D (editors). Labor and Rainfed Agriculture in West Asia and North Africa. Springer, Dordrecht.

Al-Hamwi B. 2005. Agricultural Exports in Syria. Policy Brief No: 6. Ministry of Agriculture and Agrarian Reform. National Agricultural Policy Center (NAPC).

Al-Hamwi B. 2006. Tomatoes Perspectives in Syria. Commodity Brief No: 3. Ministry of Agriculture and Agrarian Reform. National Agricultural Policy Center (NAPC).

Al-Khatib S. 2013. Syria to Remain No. 2 Olive Producer in Arab World. Available from: http://syriatimes.sy/index.php/ economy/9680-syria-to-remain-no-2-olive-producer-in-arabworld [Accessed 25 March 2018]

Almadani MIN. 2014. Risk attitude, risk perceptions and risk management strategies: an empirical analysis of Syrian wheatcotton and pistachio farmers. PhD Dissertation. Agricultural Sciences in Göttingen (IPAG) at the Faculty of Agricultural Sciences, Georg-August-University Göttingen, Germany.
Al-Shareef M. 2008. Comparative Advantages of Syrian Barley. Working Paper: 39. Ministry of Agriculture and Agrarian Reform. National Agricultural Policy Center (NAPC).

Amnesty International. 2013. Growing Restrictions, Tough Conditions: The Plight of Those Fleeing Syria to Jordan. Available from: https://www.amnestyusa.org/files/ mde160032013en.pdf [Accessed 28 May 2018]

AQUASTAT. 2018. Data: Total Renewable Water Resources. Available from: http://www.fao.org/nr/water/aquastat/data/ query/index.html [Accessed 5 April 2018]

Asmael NM, Dupuy A, Huneau F, Hamid S, Le Coustumer P. 2015. Groundwater Modeling as an Alternative Approach to Limited Data in the Northeastern Part of Mt. Hermon (Syria), to Develop a Preliminary. DOI: https://doi.org/ 10.3390/w7073978

Assessment Capacities Project (ACAPS), MapAction. 2013. Impact of the Conflict on Syrian Economy and Livelihoods. Syria Needs Analysis Project Report.

Aw-hassan A, Rida F, Telleria R, Bruggeman A. 2014. The impact of food and agricultural policies on groundwater use in Syria. Journal of Hydrology, 513: 204-215. DOI: https://doi.org/10.1016/j.jhydrol.2014.03.043

Babili M, Al Somaya K, Badro B. 2016. Measuring Syria's Exported Tomato Competitiveness in Iraqi and Russian Markets by Using Composite Competitiveness Indicator (CCI). Ministry of Agriculture and Agrarian Reform. National Agricultural Policy Center (NAPC).

Bader A, Jouni N, Shideed K. 2008. Impact of Supplemental Irrigation and the Adoption of the New Irrigation Technologies on Wheat-Based System. Water Benchmark project final report, IWLM Program, ICARDA, Aleppo, Syria.

Baghasa H. 2006a. Sheep Trade in Syria. Commodity Brief No: 4. (February). Ministry of Agriculture and Agrarian Reform. National Agricultural Policy Center (NAPC).

Baghasa H. 2006b. Table Grape Trade in Syria. Commodity Brief No: 5. June. National Agricultural Policy Center (NAPC). Syria.

Baysan N. 2001. Agricultural development strategies and southeastern Anatolia project regional development activities in the GAP region. In: Ak BE (editor). XI GREMPA Seminar on Pistachios and Almonds. Zaragoza: CIHEAM. pp. 23-28. (Cahiers Options Méditerranéennes; n. 56).

Bloomsbury Publishing. 2010. Islamic Finance: Instruments and Markets.

Cafiero C, Atiya B, Grad S, Al-Ashkar H, Sadiddin A. 2009. Study on Supply and Demand Prospects for the Major Syrian Agricultural Products. doi: 10.13140/2.1.4708.1287.

Çakmak C, Ustaoğlu M. 2015. Post-Conflict Syrian State and Nation Building: Economic and Political Development. doi: 10.1057/9781137538857.0001

CBSS, 2017. Central Bureau of Statistics of Syria. Data of Production and Yield of crops, Distribution of Irrigated areas. Available from: http://www.cbssyr.sy/index-EN.htm [Accessed 15 July 2018]

Chapman C. 2014. Syrian Agriculture: Historical and Environmental Context. United States, USAID Knowledge Services Center (KSC). Available from: http://pdf.usaid.gov/ pdf_docs/PBAAC901.pdf [Accessed 29 May 2018]

Commins DD. 2004. Historical Dictionary of Syria. Second Edition. Historical Dictionaries of Asia, Oceania, and the Middle East, No: 50. ISBN-13 978-0810849341.

Cummins G. 2000. Livestock Sub-Sector. Final Report. FAO, Ministry of Agriculture and Agrarian Reform (MAAR) and Italian Cooperation. Project GCP/SYR/006/ITA Assistance in Institutional Strengthening and Agricultural Policy. Damascus, Syria. October.

Dost M, Goodbody S, Niang M, Husain A, Bauer J-M. 2015. FAO/WFP Crop and Food Security Assessment Mission to the Syrian Arab Rebublic. 25 July 2015. 
El Ibrahem A, Abdine M, Dragotta A. 2007. The olive oil sector in Syria. In: Di Terlizzi B, Dragotta A, Jamal M (editors). Syrian national strategic plan for olive oil quality: final report. Bari: CIHEAM. Options Méditerranéennes: Série A. Séminaires Méditerranéens. n. 73.

Erian W, Katlan B, Babah O. 2010. Drought vulnerability in the Arab region: Special case study: Syria. Global Assessment Report on Disaster Risk Reduction. DOI: https://doi.org/ 10.1108/09653560810887275

European Commission. 2011. Exploring the Potential of Maritime Spatial Planning in the Mediterranean Sea. Country Reports. Syria. Available from: https://ec.europa.eu/ maritimeaffairs/sites/maritimeaffairs/files/docs/body/syria_0 1_en.pdf [Accessed 17 July 2018]

FAO, 2003. Food and Agriculture Organization of the United Nation. Fertilizer Use by Crop in the Syrian Arab Republic. Land and Plant Nutrition Management Service. Land and Water Development Division. FAO. Rome.

FAO, 2005. Food and Agriculture Organization of the United Nations. Syrian Arab Republic Nutrition Profile-Food and Nutrition Division.

FAO, 2006. Food and Agriculture Organization of the United Nations. Syrian Arab Republic. National Aquaculture Sector Overview Fact Sheets. Text by Krouma I. In: FAO Fisheries and Aquaculture Department (Online). Rome. Updated 28 January 2006.

FAO, 2007. Food and Agriculture Organization of the United Nations. Fishery Country Profile. October 2007. Available from: http://www.fao.org/fishery/docs/DOCUMENT/fcp/en/ FI_CP_SY.pdf [Accessed 5 April 2018]

FAO, 2008. Food and Agriculture Organization of the United Nations. Irrigation in the Middle East Region in Figures. AQUASTAT Survey. FAO Water Reports: 34 . Available from: http://www.fao.org/docrep/pdf/012/i0936e/i0936e00.pdf [Accessed 10 April 2018]

FAO, 2016a. Food and Agriculture Organization of the United Nations. Plan of Action for Syria: Towards Resilient Livelihoods for Sustainable Agriculture, Food Security and Nutrition. 2016-2017. Cairo, Egypt.

FAO, 2016b. Food and Agriculture Organization of the United Nations. FAO Situation Report (September).

FAO, 2017a. Food and Agriculture Organization of the United Nations. Syrian Arab Republic Situation Report (May).

FAO, 2017b. Food and Agriculture Organization of the United Nations. Syria Humanitarian Response Plan. Available from: https://ops.unocha.org/ViewReport.aspx [Accessed 5 May 2018]

FAO, 2017c. Food and Agriculture Organization of the United Nations. "FAO: Conflicts Impose \$16 Billion Losses to Syrian Agricultural Sector". Available from: http://www.fao.org/ iran/news/detail-events/en/c/878612/ [Accessed 5 May 2018]

FAO, 2018. Food and Agriculture Organization of the United Nations. FAOSTAT. Available from: http://www.fao.org/ faostat/en/\#data/ [Accessed 10 June 2018]

Feldman N. 2007. It's the Economy, Syria. Strategic Assessment, 10(3).

Fiorillo C, Vercueil J. 2003. Syrian agriculture at the crossroads. Agricultural Policy and Economic Development Series No: 8. Food and Agriculture Organization of the United Nations (FAO). Rome.

Frenken K. 2009. Irrigation in the Middle East Region in Figures. AQUASTAT Survey-2008. FAO Land and Water Division.

Gobat J, Kostial K. 2016. Syria's Conflict Economy. International Monetary Fund (IMF) Working Paper: $\mathrm{WP} / 16 / 213$.

GOSM, 2007. General Organization for Seed Multiplication. GOSM on the Technical Level. Available from: http://www.gosm.gov.sy/en/about_us.html [Accessed 15 April 2018]
Hassan N, Krepl V. 2014. Farming Systems in Syria: its Constraints and Strategies for Improvement. Scholars Journal of Agriculture and Veterinary Sciences, 1(4): 189194.

Hinnebusch R, El Hindi A, Khaddam M, Ababsa M. 2011. Agriculture and reform in Syria. St Andrews papers on contemporary Syria. University of St Andrews Centre for Syrian Studies. Fife, Scotland, UK. Available from: https://ojs.standrews.ac.uk/index.php/syria/article/view/716/620 [Accessed 10 August 2018]

Holodny E. 2016. Syria's civil war has destroyed its economy 'for years to come'. Available from: http://www.businessinsider.com/syria-economy-destroyed2016-6 [Accessed 6 August 2018]

Hosni W, Lancon F. 2011. Apple Value Chain Analysis. Working Paper No: 48. Ministry of Agriculture and Agrarian Reform. National Agricultural Policy Center (NAPC). Damascus, Syria.

IBP, 2015. International Business Publications. Syria: Energy Policy, Laws and Regulations Handbook. Volume 1. Strategic Information and Basic Laws. World Business and Investment Library, USA. ISBN-10: 1329076818.

IFAD, 2012. The International Fund for Agricultural Development. Syrian Arab Republic Integrated Livestock Development Project, Final Project Design Report. Report No: 3525-SY.

International Olive Council. 2012. General Description of Olive Growing in Syria. 1-10. Available from: http://www.internationaloliveoil.org/documents/viewfile/67 76-syria [Accessed 10 May 2018]

Işıklı E, Yercan M. 2007. Market and Trade Policies for Mediterranean Agriculture: The Case of Fruits/Vegetable and Olive-oil- EU Sixth Framework Programme.

Jaafar HH, Zurayk R, King C, Ahmad F, Al-outa R. 2015. Impact of the Syrian conflict on irrigated agriculture in the Orontes Basin. International Journal of Water Resources Development, 31(3): 436-449.

Kaisi A, Al Chayeb R, Al Zoughbi S. 2006. Water Resources in Syria: Management, Development and Women Role. $3^{\text {rd }}$ Arab Water Regional Conference: Research Advancement in Managing Limited Water Resources. 9-11 December 2006. Cairo, Egypt.

Karkout M, Lancon F. 2011. Assessment of the Competitiveness of the Syrian Agriculture: an Application to Selected Representative Value Chains. "Durum Wheat". Ministry of Agriculture and Agrarian Reform. National Agricultural Policy Center (NAPC). Working Paper No: 49.

Kelley CP, Mohtadi S, Cane MA, Seager R, Kushnir Y. 2015. Climate Change in the Fertile Crescent and Implications of the Recent Syrian Drought. Proceedings of the National Academy of Sciences of the United States of America, 112(11): 3241-3246.

Kharseh M, Nordell B. 2008. Sustainable H/C Systems for Chicken Farms in Syria.

Khoury G. 2011. Assessment of Small Scale Dairy Sector in Syria. Food and Agriculture Organization of the United Nations.

Kummu M, Ward PJ, De Moel H, Varis O. 2010. Is physical water scarcity a new phenomenon? Global assessment of water shortage over the last two millennia. Environmental Research Letter.

Leigh K. 2014. How Food Price Hikes Are Impacting Syrian Families. Available from: https://www.newsdeeply.com/syria/articles/2014/03/18/how -food-price-hikes-are-impacting-syrian-families [Accessed 13 February 2018]

Mansour F. 2007. Syrian Citrus. Qutlook No: 5. November. Ministry of Agriculture and Agrarian Reform. National Agricultural Policy Center (NAPC). 
Masri A. 2006. Country Pasture/Forage Resource Profiles. Syrian Arab Republic. Food and Agriculture Organization of the United Nations (FAO).

Mawlawi B, Tawil MW. 1990. The Role of Legumes in the Farming Systems of Syria. In: The Role of Legumes in the Farming Systems of the Mediterranean Areas. Osman AE, Ibrahim MH and Jones MA. 1990. 38. Proceedings of a Workshop on the Role of Legumes in the Farming Systems of the Mediterranean Areas UNDP/ICARDA, Tunis. 20-24 June 1988. pp. 105-114.

Mazid A, Amegbeto K, Shideed K, Malhotra R. 2009. Impact of crop improvement and man-agement: winter-sown chickpea in Syria. International Center for Agricultural Research in the Dry Areas (ICARDA), Aleppo, Syria.

Melhem R, Higano Y. 2001. Policy measures for river water management in Barada Basin, Syria. doi:10.2457/srs.32.3_1.

Mohammed N. 1986. The Development of the Seed Multiplication Program in Syria. In: Seed Production Technology. Srivastava JP and Simarski LT (editors). International Center for Agricultural Research in the Dry Areas (ICARDA), Aleppo, Syria.

Mohsen AS. 2015. Effects of Exports and Imports on the Economic Growth of Syria. Euro-Asian Journal of Economics and Finance, 3(4): 253-261. ISSN: 2310-4929 (online).

Mohsen AS, Chua SY, Sab CNC. 2016. Trade Liberalization, Exports and Imports in Syria. Foreign Trade Review. XX(X). 1-12.

Mourad KA, Berndtsson R. 2012a. Water Status in the Syrian Water Basins. Open Journal of Modern Hydrology, 2: 1520. DOI: https://doi.org/10.4236/ojmh.2012.21003

Mourad KA, Berndtsson R. 2012b. Analysis of Agricultural Production in Syria from a Virtual Water Flow Perspective. Journal of Agricultural Science and Applications (JASA), 1(3): 60-66. doi: 10.14511/jasa.2012.010301

Mustafa Y, Grando S, Ceccarelli S. 2006. Assessing the Benefits and Costs of Participatory Conventional Barley Breeding Programs in Syria. ICARDA Report for a Study Supported by the International Development Research Centre.

Nasser R, Mehchy Z, Abu Ismail K. 2013. Socioeconomic roots and impact of the Syrian Crisis. (January). The Syrian Center for Policy Research.

OCHA, 2014. United Nations Office for the Coordination of Humanitarian Affairs. Syrian Arab Republic Governorates Profile (June).

Omar AMS. 2002. Focus on Seed Programs. General Organization for Seed Multiplication.

Pala M, Ryan J, Mazid A, Abdallah O, Nachit M. 2003. Wheat farming in Syria: An approach to economic transformation and sustainability. Renewable Agriculture and Food Systems, 19(1): 30-34. doi: 10.1079/RAFS200356

Peters KJ, Kijora C, Venkataronappa MA, Achu C, Mencari G, Sa K, De Asi MF, Binh NT, Nuchmorn N, Rebai E, Vanderhasselt R. 2008. Livestock-Water Interaction in Middle East Countries: A Case Study in Syria. Winter Semester (2007-2008).

Rafei R. 2009. Stock Exchange Opening Marks Syrian Economic Shift. Tribune Newspapers: Los Angeles Times. Chicago Tribune. March 15, 2009. Available from: http://articles.chicagotribune.com/2009-03-

15/business/0903130288_1_investment-market-stockexchange-syrian [Accessed 5 May 2018]

Raphaeli N. 2007. The Political Economy of Syria Under Bashar Al-Assad. Inquiry and Analysis Series No: 343. The Middle East Media Research Institute. Available from: https://www.memri.org/reports/political-economy-syriaunder-bashar-al-assad [Accessed 5 May 2018]

Regional Food Security Analysis Network (RFSAN), Food and Agriculture Organization of the United Nations (FAO), The Institute for Measurement, Methodology, Analysis and Policy (iMMAP), the Food Security Cluster. 2016. Food Security and Livelihood Assessment (October). Syria.
Reuters. 2018. Over 500,000 Dead in Seven Years of Syrian War, Monitor Says. March 12, 2018. Available from: https://www.haaretz.com/middle-east-news/syria/over-500000-dead-in-seven-years-of-syrian-war-monitor-says1.5892068 [Accessed 13 February 2019]

RFSAN, 2016. Regional Food Security Analysis Network. Syria Agricultural Production and Cross-Border Trade Study Roundtable Policy Discussions Report (February 25).

Sadiddin A, Atiya B. 2009. Analysis of Agricultural Production for Selected Crops: Wheat, Cotton and Barley. Working Paper: 44. Damascus, Syria.

Saker SE, Othman S, Hamzeh W, Al-Rifai AH, Nassour G, Santucci FM. 2001. Agricultural Research and Extension in Syria: Present Situation and Policy Recommendations. National Agricultural Policy Center (NAPC). Working Paper No: 2.

Salman M, Mualla W. 2004. The Utilization of Water Resources for Agriculture in Syria: Analysis of Current Situation and Future Challenges. doi: 10.1142/9789812702753_0031

Sarris A. 2001. Agricultural Development Strategy for Syria. Assistance in Institutional Strengthening and Agricultural Policy. Project GCP/SYR/006/ITA. Damascus, Syria.

Shalaby AA, Haj Kassem AA, Rezk AA, Soliman AM, Youssef SA. 2007. Detection of the most important potato viruses using ELISA, RT-PCR and nucleic acid hybridization in Egypt and Syria. African Potato Association Conference Proceedings. 7. Alexandria, Egypt. pp. 228-237.

Shapland G. 1997 Rivers of Discord: International Water Disputes in the Middle East.

Sheheilah F. 2012. Identification of Export Opportunities for Syrian Citrus Growers to the EU: A Supply Chain Perspective. Dissertation at the Department of Agricultural Economics and Rural Development, Georg-August University of Göttingen.

Shhaideh A, Nahas B, Shihadeh W, Tobeh N, Kiwan N, Mousa N, Corsi A. 2000. Territorial and Structural Differentiation of Syrian Agriculture: A Case Study. Working Paper No:3. National Agricultural Policy Center (NAPC).

Shomo F, Ahmed M, Shideed K, Aw-Hassan A, Erkan O. 2010. Sources of technical efficiency of sheep production systems in dry areas in Syria. Small Ruminant Research, 91: 160169.

Sleman A, Farfour S, Babili M. 2012. The Impact of Syria's Accession to the WTO on Agricultural Sector. Working Papers 125176. Ministry of Agriculture and Agrarian Reform, National Agricultural Policy Center, Syria.

Stokes E. 2016. The Drought That Preceded Syria's Civil War Was Likely the Worst in 900 Years. Available from: https://news.vice.com/article/the-drought-that-precededsyrias-civil-war-was-likely-the-worst-in-900-years [Accessed 13 February 2019]

Subuh AM. 2008. Poultry sector country review: The Structure and Importance of the Commercial and Village based Poultry Systems in Syria. FAO, Food and Agriculture Organization of the United Nations.

Syria Independent Monitoring (SIM) Team. 2018. Understanding Market Drivers in Syria. January.

Syrian Economic Forum, Syrian Economic Task Force. 2017. Economic Map of New Syria: Agriculture, The Rehabilitation of the Agricultural Sector.

Tadesse W, Solh M, Braun H-J, Oweis T, Baum M. 2016. Approaches and Strategies for Sustainable Wheat Production. International Center for Agricultural Research in the Dry Areas (ICARDA).

The World Bank. 1987. Syria: Agricultural Sector Survey. Washington, DC. Report No: 6166-SYR.

The World Bank. 2001. Syrian Arab Republic Irrigation Sector Report: Rural Development, Water, and Environment Group, Middle East and North Africa Region. Report No: 22602-SYR. 
The World Bank. 2008. Agriculture in Syria: Towards the Social Market. Agriculture Sector Note and Technical Note on Agricultural Subsidies.

The World Bank. 2018. Data: Syrian Arab Republic Total Population. Available from: https://data.worldbank.org/ indicator/SP.POP.TOTL?end $=2015 \&$ locations $=$ SY \&start $=1$ 960\&view=chart [Accessed 27 February 2018]

Trading Economics. 2017. Syria GDP Chart. Available from: https://tradingeconomics.com/syria/gdp [Accessed 15 March 2018]

Tull K. 2017. Agriculture in Syria. K4D Helpdesk Report 133. Brighton, UK: Institute of Development Studies.

Tutwiler RN. 1995. The Great Chickpea Challenge: Introducing Winter Sowing in the Mediterranean Region. International Center for Agricultural Research in the Dry Areas (ICARDA) Social Science Papers No: 4. ISSN:1024-8005.

Ulman A, Saad A, Zylich K, Pauly D, Zeller D. 2015. Reconstruction of Syria's fisheries catches from 1950-2010: Signs of overexploitation. Acta Ichthyologica et Piscatoria, 45(3): 259-272.

UNDP, 2014. United Nations Development Programme. Reviving Tomato Farming: Farmer's livelihoods restored with the help of UNDP. Available from: http://www.sy.undp.org/content/syria/en/home/ourwork/pov ertyreduction/successstories/reviving-tomato-farming-.html [Accessed 5 May 2018]
UNW-AIS, 2008. UN-Water Activity Information System. Syria National Report on: The Actual Statues of Wastewater and Reuse for Agriculture in Syria. Available from: http://www.ais.unwater.org/ais/pluginfile.php/356/mod_pag e/content/111/Syria\%20Reusing\%20Sewage\%20and\%20tre ated $\% 20$ Water $\% 20$ for $\% 20$ Irrigation $\% 20$ and $\% 20$ its $\% 20$ Effe cts.pdf [Accessed 17 July 2018]

Varela-Ortega C, Sagardoy JA. 2003. Analysis of Irrigation Water Policies in Syria: Current Developments and Future Options. (January). Based on the FAO project: The Utilization of Water Resources for Agriculture in Syria: Analysis of the Current Regime and Policy.

Westlake M. 2000. Citrus Sector. Food and Agriculture Organization of the United Nations (FAO). Assistance in Institutional Strengthening and Agricultural Policy Project. Final Report.

World Bank Group. 2017. The Toll of War: The Economic and Social Consequences of the Conflict in Syria. Available from: http://www.worldbank.org/en/country/syria/publication/ thetoll-of-war-the-economic-and-social-consequences-of-theconflict-in-syria [Accessed 10 June 2018] 